Goldschmidt 2021 Abstract

https://doi.org/10.7185/gold2021.7132

\section{New high precision U-Pb CA-ID- TIMS zircon ages from the Terminal Ediacaran in Namibia}

\author{
FABIO MESSORI ${ }^{1}$, ULF LINNEMANN ${ }^{2}$, MANDY \\ HOFMANN $^{2}$, JOHANNES ZIEGER ${ }^{2}$, GERD GEYER ${ }^{3}$, \\ PATRICIA VICKERS-RICH ${ }^{4,5}$ AND MARIA \\ OVTCHAROVA ${ }^{1}$
}

${ }^{1}$ Dept. of Earth Sciences, University of Geneva

${ }^{2}$ Senckenberg Museum of Mineralogy and Geology

${ }^{3}$ Lehrstuhl für Geodynamik und Geomaterialforschung, Bayerische Julius-Maximilians-Universität

${ }^{4}$ School of Earth, Atmosphere and Environment, Monash

University

${ }^{5}$ Dept of Chemistry and Biotechnology, Swinburne University of Technology

Presenting Author: fabio.messori@unige.ch

The Precambrian-Phanerozoic transition marks the appearance of bilaterian animals on our planet. At that time diversified assemblages of macroscopic organisms termed 'Ediacaran biota' were replaced by modern metazoan animals of the 'Cambrian fauna'. The temporal calibration of the sedimentary record documents severe perturbations of global climates, which are considered the drivers of such biotic changes. A precise absolute age control is needed to precisely calibrate the Terminal Ediacaran turnover combined with chemostratigraphic proxies. This is complicated by the scarcity of available and coordinated geochronological and chemostratigraphic records. The Nama Group in southern Namibia serves as a unique archive for such major geobiological changes across the Ediacaran-Cambrian boundary offering near-complete sections through the Terminal Ediacaran into the Cambrian. The studied sedimentary sections record a $\mathrm{C}$ isotope excursion and host a diverse terminal Ediacaran Nama assemblage.

Here we present new high-precision $\mathrm{U}-\mathrm{Pb}$ radioisotopic age determinations (zircon CA-ID-TIMS) derived from silicified volcanic ash beds, collected in the Witputs and Zaris subbasins. Zircons derived from one ash bed in the oldest layer in the Kuibis Subgroup (on Farm Donkergange in the Zaris subbasin) yielded a weighted mean ${ }^{206} \mathrm{~Pb} /{ }^{238} \mathrm{U}$ date of $547.3 \mathrm{Ma}$, providing the best estimate for the depositional age of this bed and the end of the negative carbon isotope excursion recorded in the calcareous strata below the ash. This age is more than $0.5 \mathrm{Ma}$ younger than a previous age determination from the same ash[1]. New dates from ash beds collected from the Schwarzrand Subgroup in the Witputs subbasin (farm Witpütz-Nord and Orange River) suggest a possible stratigraphic correlation of these sections with the Swartpunt and Swartkloofberg sections, where the Ediacaran-Cambrian transition and boundary are documented and dated[2].

Our new data highlight the necessity of an overall reassessment of the stratigraphic correlations between different sections in the Witputs subbasin. Furthermore, the results demonstrate that the $\mathrm{C}$ isotope excursion in the Kuibis Subgroup is very likely younger than the presumably global Shuram-
Wonoka carbon isotope excursion (bracketed between 574 and $567 \mathrm{Ma}[3])$.

[1]Grotzinger et al., (1995), Science 270(5236), 598-604. [2]Linnemann et al., (2019), Terra Nova 31(1), 49-58. [3]Rooney et al., (2020), PNAS 117, 16824LP-16830. 